Article

\title{
Synthesis and Guest Recognition of Switchable Pt-Salphen Based Molecular Tweezers
}

\author{
Lorien Benda, Benjamin Doistau, Bernold Hasenknopf and Guillaume Vives * (D) \\ Institut Parisien de Chimie Moléculaire, Sorbonne Université, CNRS UMR 8232, 4 Place Jussieu, \\ 75005 Paris, France; lorien.benda@sorbonne-universite.fr (L.B.); benjamin.doistau@unige.ch (B.D.); \\ bernold.hasenknopf@sorbonne-universite.fr (B.H.) \\ * Correspondence: guillaume.vives@sorbonne-universite.fr; Tel.: +33-1-44-77-39-60 \\ Academic Editor: Frédéric Coutrot
}

Received: 30 March 2018; Accepted: 20 April 2018; Published: 24 April 2018

\begin{abstract}
Molecular tweezers are artificial receptors that have an open cavity generated by two recognition units pre-organized by a spacer. Switchable molecular tweezers, using a stimuli-responsive spacer, are particularly appealing as prototypes of the molecular machines that combine mechanical motion and allosteric recognition properties. In this present study, the synthesis of switchable molecular tweezers composed of a central terpyridine unit substituted in 4,4" positions by two $\mathrm{Pt}(\mathrm{II})$-salphen complexes is reported. The terpyridine ligand can be reversibly converted upon $\mathrm{Zn}$ (II) coordination from a free ' $U$ '-shaped closed form to a coordinated ' $W$ ' open form. This new substitution pattern enables a reverse control of the mechanical motion compared to the previously reported 6,6" substituted terpyridine-based tweezers. Guest binding studies with aromatic guests showed an intercalation of coronene in the cavity created by the Pt-salphen moieties in the closed conformation. The formation of 1:1 host-guest complex was investigated by a combination of NMR studies and DFT calculations.
\end{abstract}

Keywords: molecular tweezers; guest binding; terpyridine; platinum; salphen

\section{Introduction}

The concept of molecular tweezers was first introduced by Whitlock [1] who defined a molecular receptor characterized by two flat, generally aromatic, recognition sites pre-organized by a spacer to create an open cavity. Depending on the flexibility of the spacer, different recognition properties can be obtained. Rigid or semi-flexible spacers have so far been the most frequently used in the design of molecular tweezers, mostly for molecular recognition purposes [2-10]. However, stimuli-responsive spacers using redox [11,12], photochemical [13-16], $\mathrm{pH}$ [17-20] or ion coordination [21-27] stimuli have been recently used to control switchable molecular tweezers and create molecular machines or devices.

We have developed a family of switchable molecular tweezers based on a terpyridine unit substituted by metal salphen complexes with different properties depending on the metallic ion coordinated to the salphen ligand. By using a 6,6" substituted terpyridine, the tweezers can switch upon metal coordination from a " $\mathrm{W}$ "-shaped open form to a " $\mathrm{U}$ " closed form, which brings the two salphen moieties in close spatial proximity (Figure 1). This controlled and large modification of the distance between the two functional units has been successfully applied to modulate magnetic $[28,29]$ or redox properties [30] using $\mathrm{Cu}(\mathrm{II})$ and $\mathrm{Ni}(\mathrm{II})$ salphen complexes, respectively. Square planar $\mathrm{Pt}(\mathrm{II})$ luminophores present attractive properties, such as tunable excited states that are highly sensitive to their microenvironment [31]. In particular, $\mathrm{Pt}(\mathrm{II})$-salphen derivatives have been reported to exhibit high quantum efficiencies under ambient conditions [32-37]. Thus, luminescent switchable tweezers based 
on Pt(II)-salphen were developed to act as an efficient probe for guest intercalation. Although selective binding of $\mathrm{Hg}(\mathrm{II})$ coupled with a dramatic luminescence quenching was obtained in the closed form, no intercalation of flat aromatic substrates was observed [38,39]. This low affinity was attributed to the steric hindrance in the binding site caused by the cation coordinated to the terpyridine unit, which inhibits the binding of guests. To prevent the intercalation of the metal ion in the closed conformation, a new 4,4"-disubstituted terpyridine ligand was designed (Figure 1c). This new substitution pattern should result in a default ' $U$ '-shaped closed conformation, which can be converted upon metal coordination to an open ' $W$ '-shaped form. The closed conformation should enhance guest binding as observed with similar molecular clips bearing Pt-terpyridine complexes [8,40-42]. Herein we present the synthesis of Pt-based molecular tweezers as well as their switching mechanism and guest binding properties.

a)

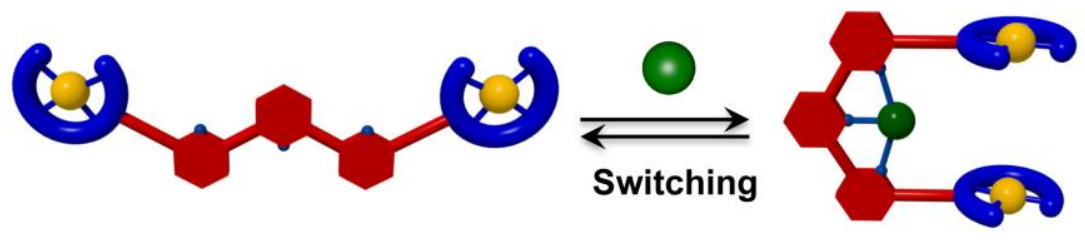

b)
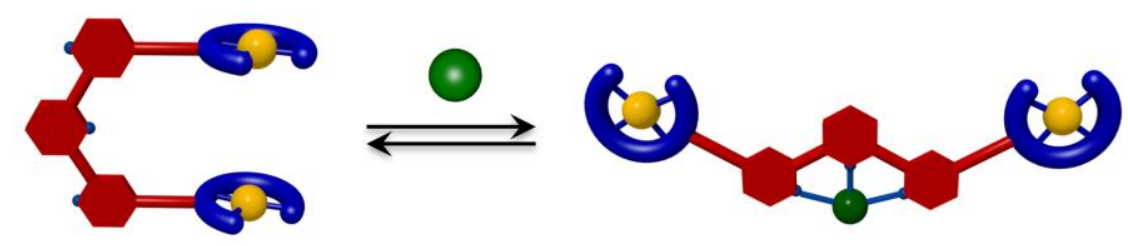

c)

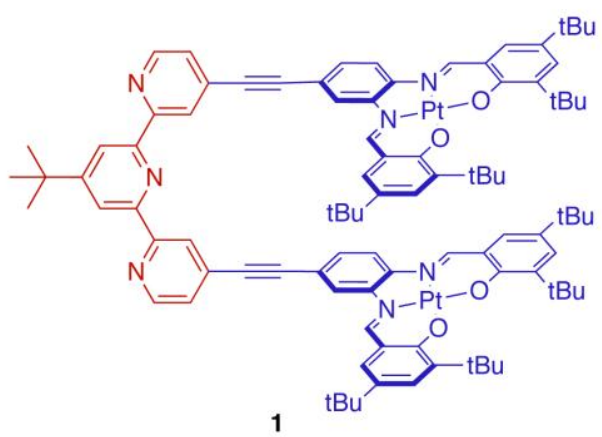

Figure 1. Schematic representation of the: (a) previous and (b) new switchable molecular tweezers; (c) molecular structure of synthetized tweezers.

\section{Results and Discussion}

\subsection{Synthesis}

The synthesis of tweezers $\mathbf{1}$ is based on a modular approach, which uses a double Sonogashira coupling reaction between 4,4" substituted di-bromo-terpyridine 4 and alkyne substituted $\mathrm{Pt}(\mathrm{II})$-salphen complex 5 as a key step (Scheme 1). Since Pt(II)-salphen complexes are inert, they can be used as building blocks in cross-coupling reactions, which enables the control of the coordination sphere of the two different salphen and terpyridine ligands. The synthesis of the 4,4" substituted terpyridine started from 2,4-dibromopyridine 2, which was acetylated by a regioselective lithium halogen exchange reaction with $n$-butyllithium followed by a reaction with $N, N$-dimethylacetamide [43]. After hydrolysis and purification by column chromatography, 3 was obtained in 56\% yield. The terpyridine ligand 4 was then synthetized using a one-pot Hantzsch-type procedure [44]. Actetyl-pyridine 3 was reacted with pivalaldehyde in the presence of potassium tert-butoxide as base in THF to form an intermediate diketo product, which was subsequently cyclized 
by ammonium acetate and oxidized by air. After purification by column chromatography on neutral aluminum oxide, 4,4"-dibromoterpyridine 4 was obtained in $29 \%$ yield.

In the last step, the terpyridine unit 4 was subjected to a double Sonogashira coupling reaction with the alkyne substituted Pt-salphen complex 5 [38]. Tweezers 1 were obtained in 33\% yield and were fully characterized by NMR spectroscopy and mass spectrometry. No exchange between $\mathrm{Pd}(\mathrm{II})$ or $\mathrm{Cu}(\mathrm{I})$ and $\mathrm{Pt}(\mathrm{II})$ was detected, confirming the non-lability of $\mathrm{Pt}(\mathrm{II})$-salphen complexes and validating our 'chemistry on complex' strategy.

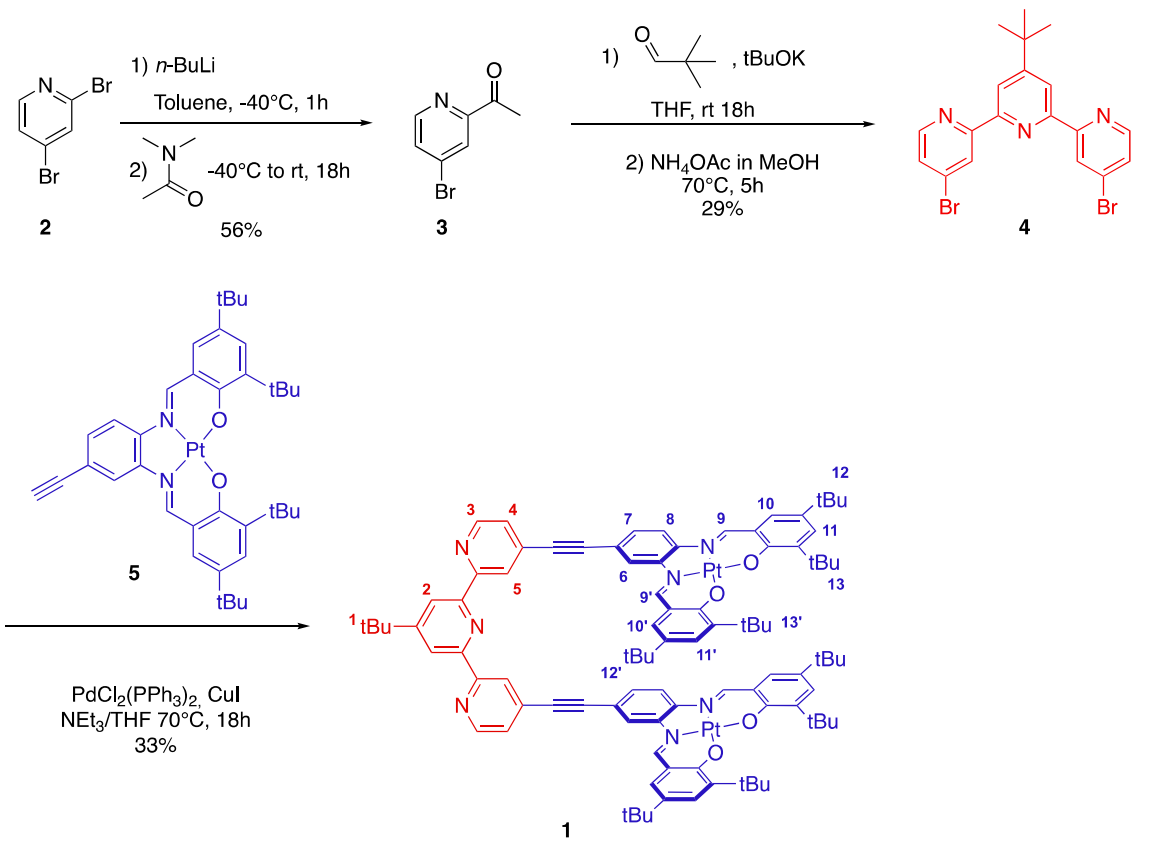

Scheme 1. Synthesis of molecular tweezers 1.

\subsection{Switching Studies}

The conformation of tweezers 1 was first investigated by ${ }^{1} \mathrm{H}$ NMR spectroscopy. The 2D NOESY spectrum in $\mathrm{CDCl}_{3}$ is consistent with a ' $\mathrm{U}$ '-shaped geometry of the terpyridine ligand with the absence of correlation between the H-2 and $\mathrm{H}-5$ protons (see Figure S1). This is expected due to the electronic repulsion between the nitrogen lone pairs favoring the s-trans conformation. Due to the dissymmetric substitution pattern of the Pt-salphen moiety, the closed conformation can exist as synor anti-conformers (Figure 2a,b). The cross-peaks between H-7 and H-12' and between H-10 and H-13' (Figure 2c) indicate a short distance between the two Pt-salphen complexes, which can be observed only if the two moieties adopt the anti-conformation. To obtain a better insight into the conformation of the tweezers, DFT calculations were performed. In the U-shaped form, the terpyridine ligand adopts a slightly twisted geometry, resulting in a folded helical structure with the two arms in the anti-conformation crossing at the level of the salphen units (Figure 3). The resulting minimal distance between $\mathrm{H}-7$ and $\mathrm{H}-12$ ' is approximately $2.3 \AA$, which explains the obtained correlation in the NOESY spectrum. DFT calculations were also performed for the open W-shaped form. In the optimized structure, the terpyridine ligand is not co-planar as each pyridine moiety displays an average dihedral angle of $32^{\circ}$ to minimize the repulsion between the nitrogen lone pairs (Figure S2). As expected, the energy of the $\mathrm{W}$ form is higher than the U-shaped one of around $80 \mathrm{~kJ} \cdot \mathrm{mol}^{-1}$. This significant difference is probably due to a combination of the destabilization of the s-cis conformation of the terpyridine unit in the $\mathrm{W}$-shaped form and a stabilizing interaction between the two Pt-salphen units in the closed U-shaped conformation.

The opening of tweezers $\mathbf{1}$ was monitored by UV-Vis spectroscopy in chloroform. Titration of $\mathbf{1}$ with $\mathrm{ZnCl}_{2}$ (Figure 4) showed a single evolution up to 0.5 equivalents of $\mathrm{Zn}^{2+}$ with isosbestic points at 
the three curve crossings $(\lambda=605,310$ and $286 \mathrm{~nm})$. This is consistent with an equilibrium between only two species corresponding to free and coordinated tweezers. The linear evolution with a sharp endpoint at 0.5 eq. of $\mathrm{Zn}^{2+}$ indicates the formation of the bis-terpyridine 2:1 complex $\left[\mathrm{Zn}(\mathbf{1})_{2}\right]^{2+}$. The formation of a 2:1 complex was confirmed by mass spectrometry with a signal at $1834 \mathrm{~m} / \mathrm{z}$, which corresponds to di-cationic $\left[\mathrm{Zn}(\mathbf{1})_{2}\right]^{2+}$ species (Figure S5). Fitting of the titration curve with a 2:1 model revealed very strong association constants $\left(\log K_{1}, K_{2}>8\right)$, which are similar to those previously observed with terpyridine ligands $[45,46]$. The switching was also monitored by ${ }^{1} \mathrm{H}-\mathrm{NMR}$ in DMSO- $\mathrm{d}_{6}$ due to the low solubility of $\left[\mathrm{Zn}(1)_{2}\right] \mathrm{Cl}_{2}$ in $\mathrm{CDCl}_{3}$, toluene or $\mathrm{CDCl}_{3} / \mathrm{CD}_{3} \mathrm{CN}$ mixtures. Upon addition of $\mathrm{ZnCl}_{2}$, progressive disappearance of the signals of closed tweezers $\mathbf{1}$ is observed with only one set of new signals appearing corresponding to $\left[\mathrm{Zn}(\mathbf{1})_{2}\right] \mathrm{Cl}_{2}$ (Figure S3). An excess of $\mathrm{ZnCl}_{2}$ was necessary to fully convert 1 to $\left[\mathrm{Zn}(\mathbf{1})_{2}\right] \mathrm{Cl}_{2}$ due to the competition of the solvent coordination with $\mathrm{Zn}^{2+}[47,48]$. The spectrum of open tweezers (Figure $5 \mathrm{~b}$ ) is characteristic of a coordinated terpyridine ligand with downfield shifts for meta-protons $\mathrm{H}-2$ and $\mathrm{H}-4$ compared to the open tweezers. Large shifts are also observed for the protons of the Pt-salphen moieties. In particular, $\mathrm{H}-7$ and $\mathrm{H}-8$ protons in addition to $\mathrm{H}-9$ and $\mathrm{H}-9^{\prime}$ imine protons are strongly deshielded. The open conformation prevents the intramolecular stacking between the Pt-salphen units and results in a loss of magnetic anisotropy effects present in the closed conformation. The 2D NOESY spectrum is consistent with a $\mathrm{W}$-shaped geometry of the terpyridine ligand with a correlation peak between $\mathrm{H}-2$ and $\mathrm{H}-5$ protons (Figure S4).

a)
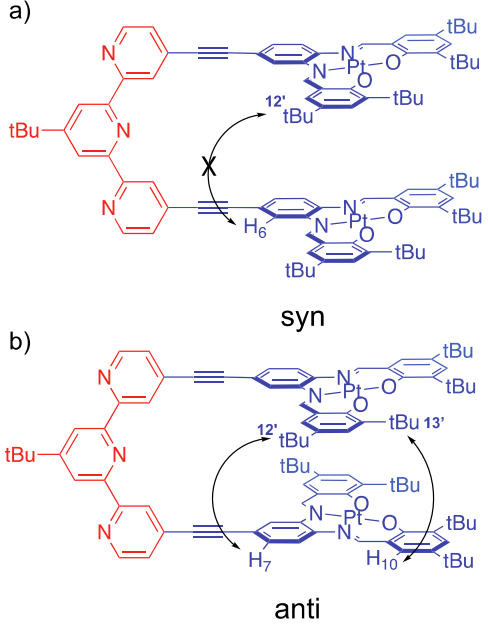

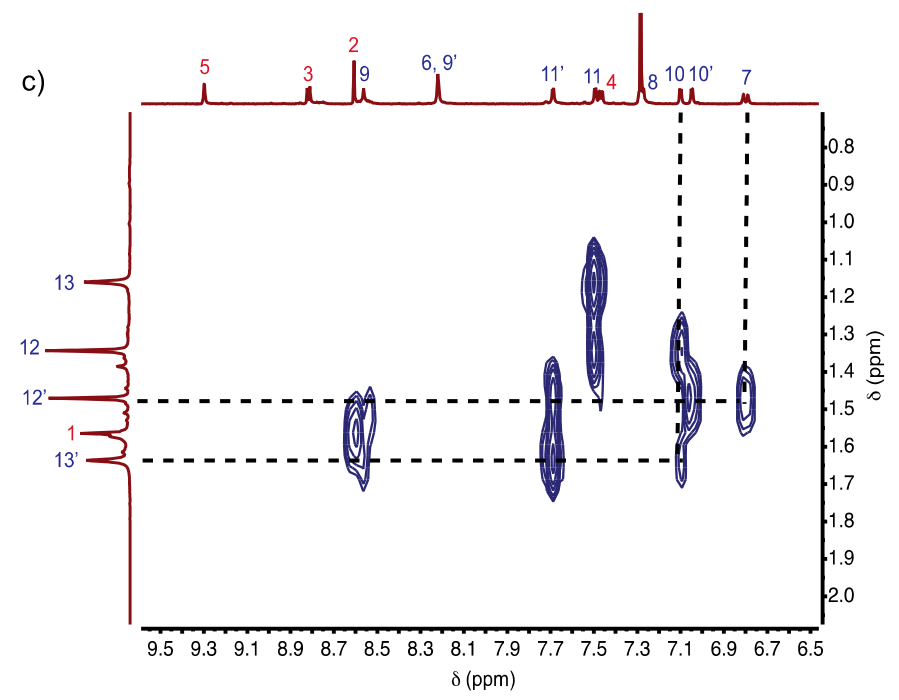

Figure 2. (a,b) Molecular structure of the syn- and anti-conformations and (c) ${ }^{1} \mathrm{H}$ NOESY Spectrum (400 MHz, $300 \mathrm{~K}$ ) of $\mathbf{1}$ in $\mathrm{CDCl}_{3}$ showing the correlation peaks between $\mathrm{H}-7 / \mathrm{H}-12^{\prime}$ and $\mathrm{H}-10 / \mathrm{H}-13^{\prime}$ indicative of a closed stacked anti-conformation.

a)

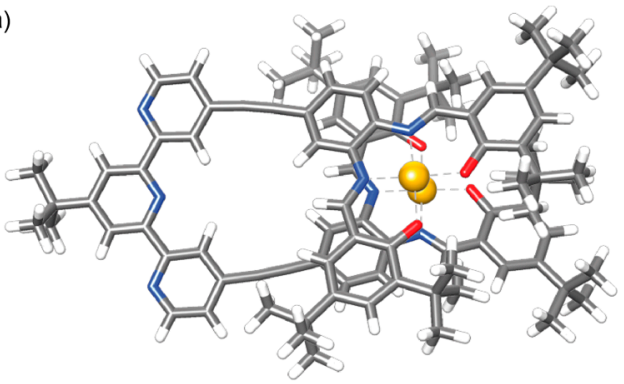

b)

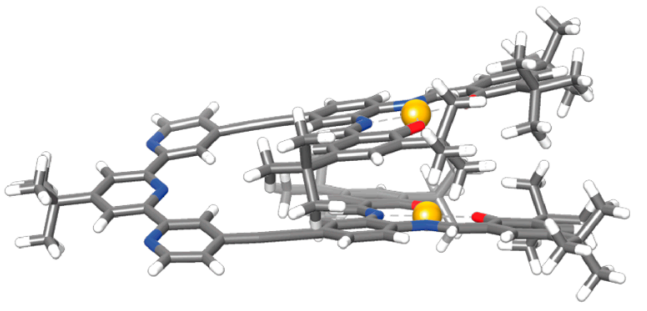

Figure 3. DFT-optimized structure of $\mathbf{1}$ (B3LYP/6-31G**/LanL2DZ); (a) top view and (b) side view. 


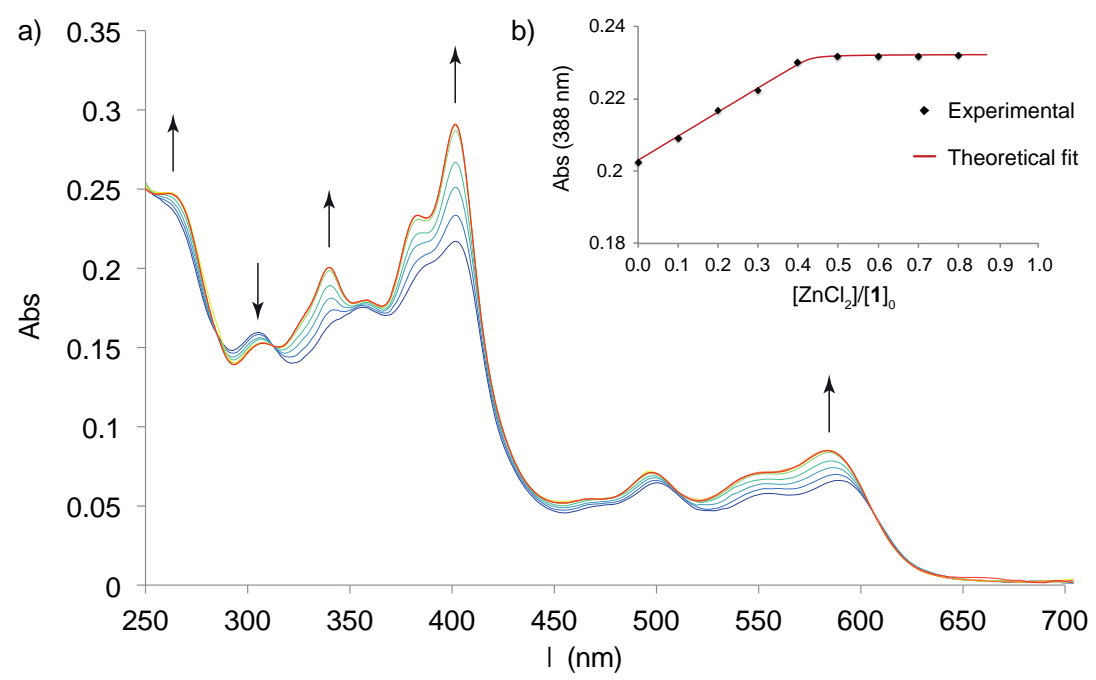

Figure 4. (a) UV-Vis titration of $1\left(5.0 \times 10^{-6} \mathrm{~mol} \cdot \mathrm{L}^{-1}\right)$ by $\mathrm{ZnCl}_{2}$ in $\mathrm{CHCl}_{3}$ and (b) Absorption at $388 \mathrm{~nm}$ and fitting with a 2:1 binding model.

a)

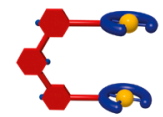

b)

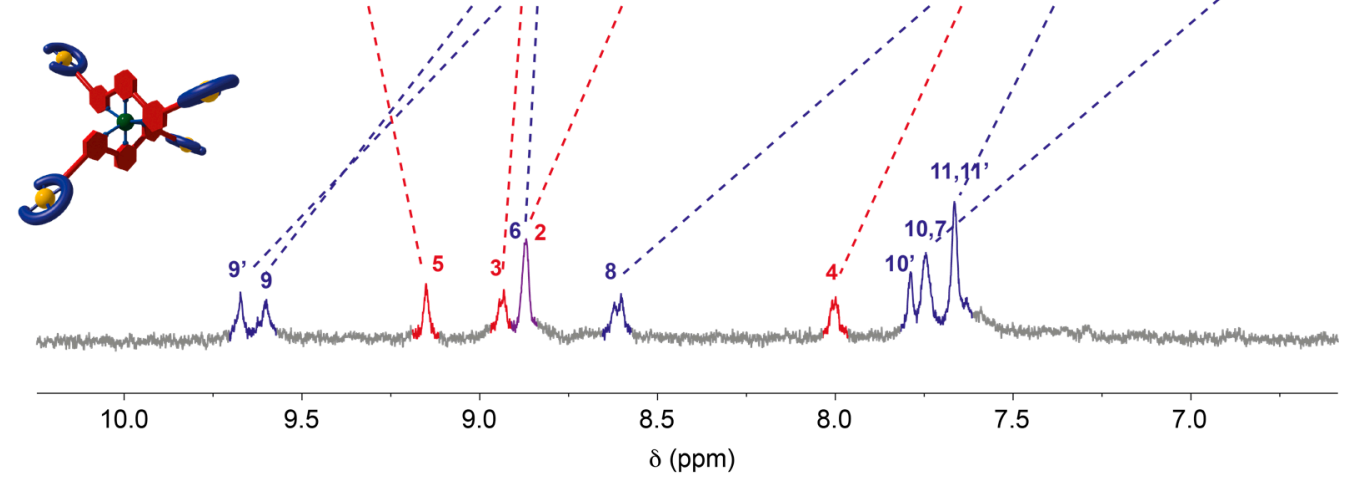

Figure 5. ${ }^{1} \mathrm{H}$ NMR spectra $(400 \mathrm{MHz}, 300 \mathrm{~K})$ in DMSO-d $\mathrm{d}_{6}$ of: (a) tweezers $\mathbf{1}$ and (b) $\left[\mathrm{Zn}(\mathbf{1})_{2}\right] \mathrm{Cl}_{2}$.

The reversibility of the molecular motion was investigated by addition of a competitive ligand to remove the $\mathrm{Zn}^{2+}$ from the terpyridine. Tris 2-aminoethyl amine (tren) was chosen due to its high binding constant with metallic cations [49]. The closing of the tweezers previously opened with $\mathrm{Zn}^{2+}$ was investigated by UV-Vis titration (Figure 6). A complete reclosing was observed after the addition of around $1.2 \mathrm{eq}$ of tren. The presence of isosbestic points at all curve crossings $(\lambda=310$ and $286 \mathrm{~nm}$ ) is consistent with only two absorbing species being in equilibrium (open and closed) with the reclosing following the reverse path of the opening. This demonstrates the reversible working operation of tweezers 1 that can be opened and closed with the opposite stimuli to those used for the 6,6 " substituted terpyridine based tweezers that we have previously reported [38,39]. 


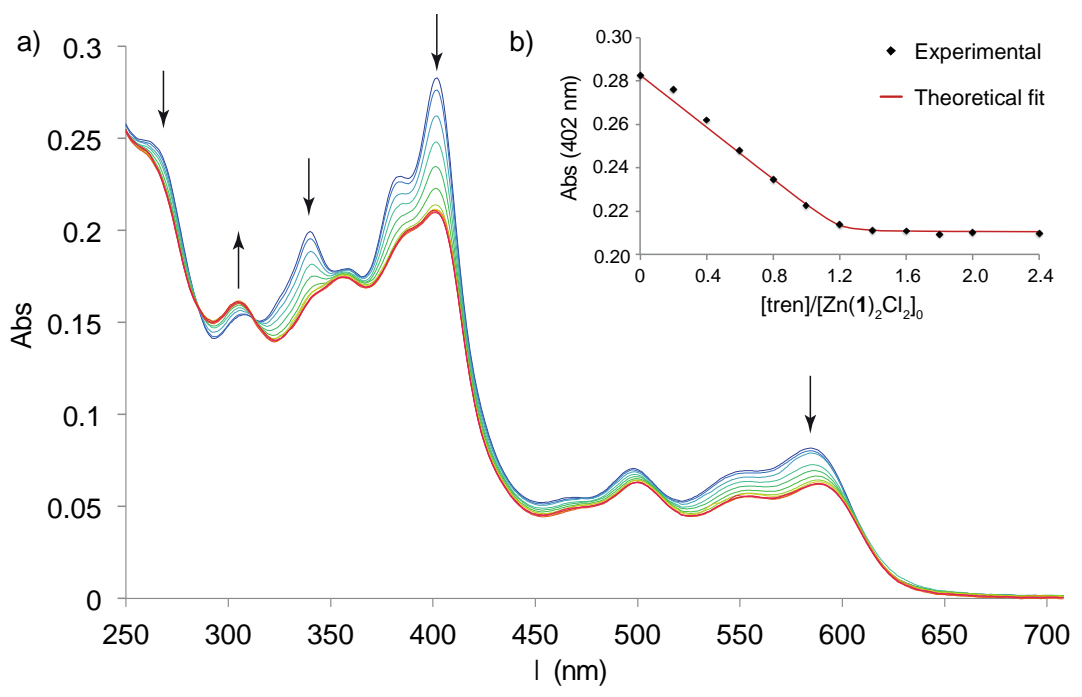

Figure 6. (a) UV-Vis titration of $\left[\mathrm{Zn}(\mathbf{1})_{2}\right] \mathrm{Cl}_{2}\left(5.0 \times 10^{-6} \mathrm{~mol} \cdot \mathrm{L}^{-1}\right)$ upon the addition of tren in $\mathrm{CHCl}_{3}$, after the opening with 0.5 equivalent of $\mathrm{ZnCl}_{2}$ and (b) Absorption at $402 \mathrm{~nm}$ and fitting with a 1:1 binding model.

\subsection{Guest-Binding Studies}

The recognition and intercalation abilities of tweezers 1 towards flat aromatic guest molecules were then investigated by analogy with bis(Pt-terpyridine) molecular clips, which have been reported in the literature $[8,9,40,42]$. Titration experiments were monitored by ${ }^{1} \mathrm{H} \mathrm{NMR}$ in $\mathrm{CDCl}_{3}$ at $300 \mathrm{~K}$. Upon addition of coronene, large upfield shifts for phenylene $\mathrm{H}-7, \mathrm{H}-8$ and $\mathrm{H}-6$ protons $(\Delta \delta$ of ca. -0.6 to $-0.9 \mathrm{ppm}$ ) as well as $\mathrm{H}-9$ and $\mathrm{H}-9^{\prime}$ imine protons $(\Delta \delta$ of ca. $-1.1 \mathrm{ppm}$ ) were observed (Figure $7 \mathrm{a})$, which are probably due to the $\pi$-stacking interactions between the salphen moiety and the coronene. In addition, the signal of coronene was also shifted upfield by approximately $0.2 \mathrm{ppm}$. The protons of the terpyridine unit, $\mathrm{H}-3$ and $\mathrm{H}-4$, are less affected. Only the $\mathrm{H}-5$ and $\mathrm{H}-2$ protons showed a small downfield shift ( $\Delta \delta$ of ca. $+0.1 \mathrm{ppm}$ ), indicating weak interactions between the coronene and the terpyridine unit. These shifts are consistent with recognition taking place inside the cavity formed by the two Pt-salphen units. Upon lowering the temperature in $\mathrm{CD}_{2} \mathrm{Cl}_{2}$, the broadening of the NMR signals was observed for a 1:1.5 mixture of $\mathbf{1}$ and coronene, with a coalescence that was reached at around $220 \mathrm{~K}$ (Figure S6). At $190 \mathrm{~K}$, two sets of signals were observed for all peaks, which indicates the transition from a fast to slow exchange upon cooling. Since the major set of signals have the same chemical shifts as the free tweezers at $190 \mathrm{~K}$, the minor ones can be attributed to the host/guest complex.

To obtain a better insight into the interaction between coronene and 1, 2D NOESY experiments on a 1:1.5 mixture of tweezers 1 and coronene were performed. No correlation between the coronene protons and $\mathbf{1}$ were observed in NOESY, which is probably due to the fast exchange and relatively low binding constant. However, the extinction of the correlations between $\mathrm{H}-7$ and $\mathrm{H}-12^{\prime}$ and between $\mathrm{H}-10$ and H-13' (Figure S7) is indicative of an increased distance between the two Pt-salphen units as expected from the intercalation of coronene. The formation of a 1:1 complex [coronene $\subset$ 1] was confirmed by mass spectrometry, with characteristic peaks at $2101.9,2123.8$ and $2139.8 \mathrm{~m} / \mathrm{z}$ (see Figure S8) corresponding to the mono-charged species [coronene $\subset \mathbf{1}+\mathrm{H}]^{+}$, [coronene $\left.\subset \mathbf{1}+\mathrm{Na}\right]^{+}$and [coronene $\subset \mathbf{1}+\mathrm{K}]^{+}$, respectively. The binding constant between the coronene and tweezers $\mathbf{1}$ was determined by fitting the NMR titration data with a 1:1 binding model [50] (Figure 7b). The obtained value $\left(\mathrm{K}=300 \pm 15 \mathrm{M}^{-1}\right)$ is moderate compared to the aromatic binding reported in the literature with bis(Pt-terpyridine) molecular clips $[6,40,42]$. This is probably due to the bulky tert-butyl groups introduced for solubility reasons, which prevent a strong $\pi$-stacking interaction between the Pt-salphen moieties and the coronene. However, it should be noted that the bis(Pt-terpyridine) molecular clips reported by Yam or Bosnich $[6,40,42]$ use cationic Pt-terpyridine complexes as recognition units. 
Compared to the neutral Pt-salphen units of tweezers 1, the electron poor and charged units might improve the binding with aromatic substrates via enhanced donor/acceptor and ion/ $\pi$ interactions.
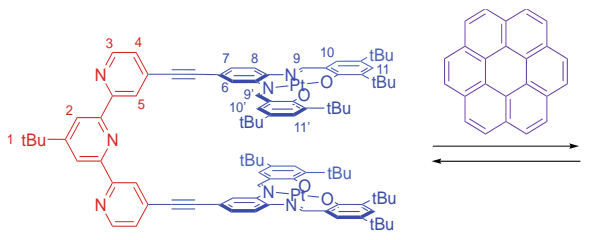

a)

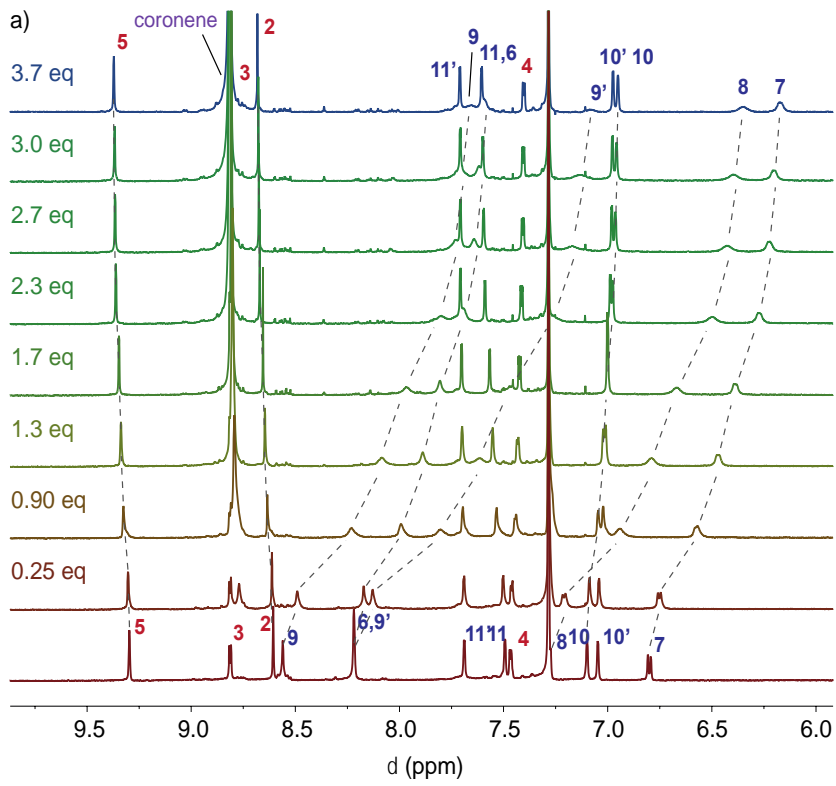

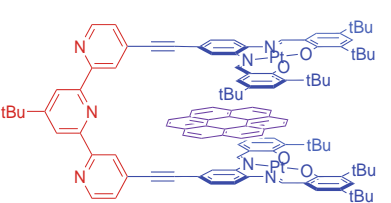

b)

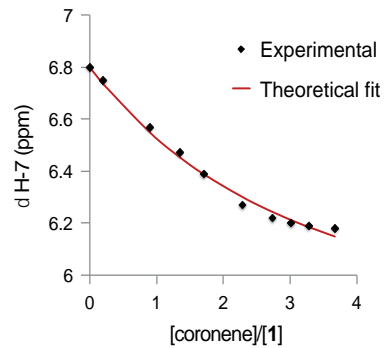

c)

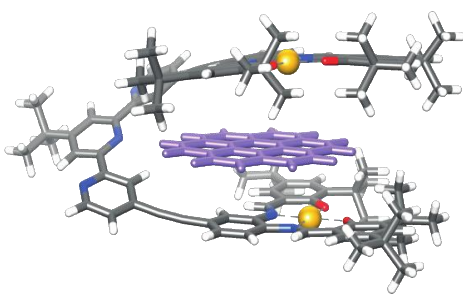

Figure 7. (a) ${ }^{1} \mathrm{H}-\mathrm{NMR}(600 \mathrm{MHz})$ titration of Tweezers $1(2.0 \mathrm{mM})$ with coronene in $\mathrm{CDCl}_{3}$ at $300 \mathrm{~K}$; (b) Fitting with a 1:1 binding isotherm model; and (c) DFT-optimized structure of the host guest complex [coronene $\subset$ 1] (B3LYP/6-31G**/LanL2DZ).

Diffusion ordered NMR spectroscopy (DOSY) experiments were also performed in $\mathrm{CDCl}_{3}$ at $300 \mathrm{~K}$ to provide additional evidence for the binding of coronene. The diffusion coefficients of tweezers 1 and coronene are $9.06 \times 10^{-10} \mathrm{~m}^{2} \cdot \mathrm{s}^{-1}$ and $1.38 \times 10^{-9} \mathrm{~m}^{2} \cdot \mathrm{s}^{-1}$, respectively, whereas the 1:1.5 mixture presents values of $6.79 \times 10^{-10} \mathrm{~m}^{2} \cdot \mathrm{s}^{-1}$ for 1 and $1.31 \times 10^{-9} \mathrm{~m}^{2} \cdot \mathrm{s}^{-1}$ for the coronene. The diffusion coefficient of the coronene is slightly lowered in the mixture, which indicates that a non-negligible amount of the guest is accommodated in the tweezers. The diffusion constant of Tweezers $\mathbf{1}$ is also significantly reduced by the presence of coronene, which suggests an increase in the hydrodynamic radius as expected from the intercalation of the guest that moves the Pt-salphen moieties apart. The exact binding mode for the complex [coronene $\subset$ 1] was further clarified by DFT calculations (Figure 7c). In the optimized structure, the coronene is intercalated between the two Pt-salphen units with inter-planar $\pi$-distances that were calculated to be approximately $3.8 \AA$. The close proximity between the coronene and the diamino-phenylene and imine moieties of the salphen is consistent with the remarkable upfield shifts of NMR signals for the corresponding protons. The distance between the two salphens increased from 4.5 to $7.6 \AA$ in the presence of the guest, which is in agreement with the increased hydrodynamic radius observed by DOSY as well as with the absence of correlation between protons $\mathrm{H}-7$ and $\mathrm{H}-12^{\prime}$ and between $\mathrm{H}-10$ and $\mathrm{H}-13^{\prime}$ in NOESY.

The release of the coronene guest by opening the tweezers with $\mathrm{Zn}(\mathrm{II})$ was also investigated. Whereas the coronene recovers the chemical shift of the free species upon the addition of $\mathrm{ZnCl}_{2}$ to a solution of [coronene $\subset 1$ ] in $\mathrm{CDCl}_{3}$, the formed zinc complex becomes insoluble and precipitates. This indicates that a release of the guest occurs as expected from the opening, but the concomitant precipitation of the open tweezers precludes its unambiguous attribution to the mechanical motion. 
Different $\mathrm{Zn}$ (II) salts or solvent mixtures were tried but unfortunately, no combination was found where all species (coronene and zinc tweezers) remained soluble at the NMR concentration.

Finally, the binding of smaller aromatic guests was examined. Upon addition of perylene, small shifts were observed by NMR (Figure S9), indicating some intercalation. However, the binding constant was too low to be accurately determined. Surprisingly, the addition of a Pt-salphen complex where Pt-Pt interactions should provide an additional driving force [41,51] did not result in any intercalation. The tert-butyl groups on the Pt-salphen units introduced for solubility reasons are probably preventing optimal positioning of the guest to combine $\pi$-stacking and Pt-Pt interactions.

\section{Materials and Methods}

\subsection{General Procedures}

Reagent grade tetrahydrofuran was distilled from sodium and benzophenone. Tetrahydrofuran and triethylamine were degassed by three freeze-pump-thaw cycles before being used in the Sonogashira coupling reactions. All other chemicals were purchased from commercial suppliers and used without further purification. Complex 5 was synthetized according to the literature [38]. Flash column chromatography was performed using silica gel from Merck $(40-63 \mu \mathrm{m})$ or GraceResolv High Resolution Flash Cartridges (particle size of $40 \mu \mathrm{m}$ ). Thin layer chromatography was performed using aluminum plates pre-coated with silica gel or neutral aluminum oxide 60 F254 purchased from VWR, which had a 0.20-mm layer thickness. Absorption spectra were recorded on a JASCO V-670 spectrophotometer. Infrared spectra were recorded on a Bruker tensor 27 ATR spectrometer. Electrospray ionization (ESI) mass spectrometry was performed on a Bruker microTOF spectrometer.

\subsection{Synthesis}<smiles>CC(=O)c1ccc(Br)[14cH]n1</smiles>

4-Bromo-2-acetylpyridine 3 [43]. In a round bottom flask, 2,4-dibromopyridine 2 (4.0 g, $17 \mathrm{mmol}, 1 \mathrm{eq})$ was dissolved in $160 \mathrm{~mL}$ of dry toluene. The solution was cooled down to $-40{ }^{\circ} \mathrm{C}$ and $n$-Buli $(11 \mathrm{~mL}$ of a solution at $1.6 \mathrm{M}$ in hexane, $17 \mathrm{mmol}, 1 \mathrm{eq}$ ) was added dropwise. The mixture was stirred for $1.5 \mathrm{~h}$ at $-40{ }^{\circ} \mathrm{C}$. $\mathrm{N}, \mathrm{N}$-dimethylacetamide $(2.6 \mathrm{~g}, 30 \mathrm{mmol}, 1.8 \mathrm{eq})$ was added and the mixture was allowed to return to room temperature and stirred for $1 \mathrm{~h}$. A saturated solution of $\mathrm{NH}_{4} \mathrm{Cl}$ (around $50 \mathrm{~mL}$ ) was added and the organic phase was separated. The aqueous phase was extracted with $\mathrm{CHCl}_{3}$ and the combined organic phases were dried over $\mathrm{MgSO}_{4}$. The solvents were evaporated under reduced pressure, before the crude product was purified by column chromatography $\left(\mathrm{SiO}_{2}\right.$ : from Cyclohexane/EtOAc (70/30) to EtOAc (100)), yielding 3 as a white solid $(1.83 \mathrm{~g}, 56 \%) .{ }^{1} \mathrm{H}$ NMR $\left(400 \mathrm{MHz}, 300 \mathrm{~K}, \mathrm{CDCl}_{3}\right) \delta 8.51\left(\mathrm{dd}, J=5.2,0.6 \mathrm{~Hz}, 2 \mathrm{H}, \mathrm{H}_{1}\right), 8.20\left(\mathrm{dd}, J=1.8,0.6 \mathrm{~Hz}, 1 \mathrm{H}, \mathrm{H}_{3}\right) 7.65(\mathrm{dd}$, $\left.J=1.8,5.2 \mathrm{~Hz}, 1 \mathrm{H}, \mathrm{H}_{2}\right), 1.59\left(\mathrm{~s}, 3 \mathrm{H}, \mathrm{H}_{4}\right) ;{ }^{13} \mathrm{C} \mathrm{NMR}\left(100 \mathrm{MHz}, 300 \mathrm{~K}, \mathrm{CDCl}_{3}\right) \delta 198.70,154.30,149.69$, 134.11, 130.19, 125.27, 25.83.

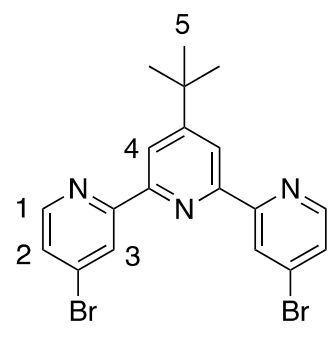


4,4"-Dibromo-4'-(tert-butyl)-2,2':6',2"-terpyridine 4. 4-bromo-2-acetylpyridine 3 (700 mg, $3.50 \mathrm{mmol}, 2 \mathrm{eq}$ ) was added to a suspension of $t$-BuOK $(590 \mathrm{mg}, 5.25 \mathrm{mmol}, 3 \mathrm{eq})$ in THF $(25 \mathrm{~mL})$. Pivalaldehyde $(150 \mathrm{mg}$, $1.75 \mathrm{mmol}, 1 \mathrm{eq}$ ) was added and the mixture was stirred at room temperature for $18 \mathrm{~h}$. A solution of $\mathrm{NH}_{4} \mathrm{OAc}(1.50 \mathrm{~g}, 19.25 \mathrm{mmol}, 11 \mathrm{eq})$ in $\mathrm{MeOH}(10 \mathrm{~mL})$ was introduced, before the mixture was heated at $70{ }^{\circ} \mathrm{C}$ for $5 \mathrm{~h}$. After solvent evaporation, the crude product was purified by a short column chromatography $\left(\mathrm{Al}_{2} \mathrm{O}_{3}\right.$ : Cyclohexane/Ethyl Acetate (96/4)), yielding dibromo-terpyridine 4 as a white solid (256 mg, 29\%). ${ }^{1} \mathrm{H}$ NMR $\left(400 \mathrm{MHz}, 300 \mathrm{~K}, \mathrm{CDCl}_{3}\right) \delta 8.76\left(\mathrm{dd}, J=0.4,2.0 \mathrm{~Hz}, 2 \mathrm{H}, \mathrm{H}_{3}\right)$, $8.53\left(\mathrm{dd}, J=0.4,5.3 \mathrm{~Hz}, 2 \mathrm{H}, \mathrm{H}_{1}\right), 8.51\left(\mathrm{~s}, 2 \mathrm{H}, \mathrm{H}_{4}\right), 7.51\left(\mathrm{~J}=2.0,5.3 \mathrm{~Hz}, 2 \mathrm{H}, \mathrm{H}_{2}\right), 1.46\left(\mathrm{~s}, 9 \mathrm{H}, \mathrm{H}_{5}\right)$; ${ }^{13} \mathrm{C}$ NMR $\left(100 \mathrm{MHz}, 300 \mathrm{~K}, \mathrm{CDCl}_{3}\right) \delta 162.68,157.83,154.38,149.93,134.04,127.02,124.83,119.26,35.58$, 30.85. ESI-HRMS $m / z$ : [M+Na] ${ }^{+}$calculated $\left(\mathrm{C}_{19} \mathrm{H}_{17} \mathrm{~N}_{3} \mathrm{Br}_{2} \mathrm{Na}\right)$ : 469.9662 , found: 469.9667.

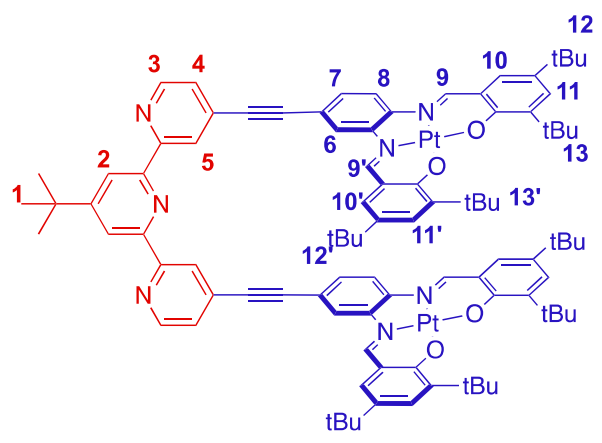

Tweezers 1. In a Schlenk tube, terpyridine 4 ( $39 \mathrm{mg}, 0.087 \mathrm{mmol}, 1 \mathrm{eq})$, complex 5 ( $263 \mathrm{mg}, 0.35 \mathrm{mmol}$, $4 \mathrm{eq}), \mathrm{PdCl}_{2}\left(\mathrm{PPh}_{3}\right)_{2}(12 \mathrm{mg}, 0.017 \mathrm{mmol}, 20 \mathrm{~mol} \%)$ and $\mathrm{CuI}(7 \mathrm{mg}, 0.035 \mathrm{mmol}, 40 \mathrm{~mol} \%)$ were introduced and placed under an Argon atmosphere. After this, a mixture of $\mathrm{NEt}_{3}(5 \mathrm{~mL}) / \mathrm{THF}(10 \mathrm{~mL})$ that was previously distilled and degassed by freeze pump thaw cycles was added. The mixture was stirred at $70{ }^{\circ} \mathrm{C}$ under argon for $18 \mathrm{~h}$. After solvent evaporation, the purple crude product was finally purified by column chromatography $\left(\mathrm{SiO}_{2}\right.$ : from cyclohexane/dichloromethane $(50 / 50)$ to dichloromethane/methanol (92/8)), yielding tweezers 1 as a purple solid (52 mg, 33\%). ${ }^{1} \mathrm{H}$ NMR $\left(400 \mathrm{MHz}, \mathrm{CD}_{2} \mathrm{Cl}_{2}\right) \delta$ of $9.33\left(\mathrm{dd}, J=0.7,1.5 \mathrm{~Hz}, 2 \mathrm{H}, \mathrm{H}_{5}\right), 8.79\left(\mathrm{dd}, J=0.7,5.0 \mathrm{~Hz}, 2 \mathrm{H}, \mathrm{H}_{3}\right), 8.61(\mathrm{~s}$, $\left.2 \mathrm{H}, \mathrm{H}_{2}\right), 8.57\left(\mathrm{~s}, 2 \mathrm{H}, \mathrm{H}_{9}\right), 8.27\left(\mathrm{~d}, J=1.2 \mathrm{~Hz}, 2 \mathrm{H}, \mathrm{H}_{6}\right), 8.25\left(\mathrm{~s}, 2 \mathrm{H}, \mathrm{H}_{9^{\prime}}\right), 7.70\left(\mathrm{~d}, J=2.2 \mathrm{~Hz}, 2 \mathrm{H}, \mathrm{H}_{11^{\prime}}\right)$, $7.48\left(\mathrm{~m}, 4 \mathrm{H}, \mathrm{H}_{11-4}\right), 7.28\left(\mathrm{~d}, J=8.6 \mathrm{~Hz}, 2 \mathrm{H}, \mathrm{H}_{8}\right), 7.12\left(\mathrm{~d}, J=2.5 \mathrm{~Hz}, 2 \mathrm{H}, \mathrm{H}_{10}\right), 7.05(\mathrm{~d}, J=2.2 \mathrm{~Hz}, 2 \mathrm{H}$, $\left.\mathrm{H}_{10^{\prime}}\right), 6.82\left(\mathrm{dd}, J=1.2,8.6 \mathrm{~Hz}, 2 \mathrm{H}, \mathrm{H}_{7}\right), 1.61\left(\mathrm{~s}, 18 \mathrm{H}, \mathrm{H}_{13^{\prime}}\right), 1.53\left(\mathrm{~s}, 9 \mathrm{H}, \mathrm{H}_{1}\right), 1.46\left(\mathrm{~s}, 18 \mathrm{H}, \mathrm{H}_{12^{\prime}}\right), 1.33(\mathrm{~s}$, $\left.18 \mathrm{H}, \mathrm{H}_{12}\right), 1.13\left(\mathrm{~s}, 18 \mathrm{H}, \mathrm{H}_{13}\right) ;{ }^{13} \mathrm{C}$ NMR $\left(100 \mathrm{MHz}, \mathrm{CD}_{2} \mathrm{Cl}_{2}\right) \delta 165.29,164.53,163.66,157.10,154.80$, 150.21, 149.64, 147.74, 146.36, 145.30, 141.83, 141.70, 137.55, 137.44, 132.51, 131.66, 131.51, 129.59, 129.47, $128.91,125.76,124.40,121.37,120.99,119.72,118.42,114.83,94.30,89.83,36.81,36.34,36.06,34.58,34.35$, $31.68,31.53,31.14,30.62,29.95$. ESI-HRMS $m / z:[\mathrm{M}+\mathrm{Na}]^{+}$calculated $\left(\mathrm{C}_{95} \mathrm{H}_{107} \mathrm{~N}_{7} \mathrm{Pt}_{2} \mathrm{O}_{4}\right): 1823.759$, found: 1823.7589 .

\subsection{Titration Procedures}

${ }^{1} \mathrm{H}$ NMR titrations were performed using $\mathrm{CDCl}_{3}$ dried over molecular sieves (4 $\AA$ ), which were passed through dried neutral aluminum oxide. Metal salts and tris(2-aminoethyl)amine were used without any purification. All solutions of tweezers, metal salts and ligands used for titrations were prepared in volumetric flasks, while the additions were made with Hamilton syringes.

Tweezers 1 opening: To $0.5 \mathrm{~mL}$ of closed tweezers $1\left(1.0 \times 10^{-3} \mathrm{M}\right)$ dissolved in DMSO- $d_{6}$ in an NMR tube $(5 \mathrm{~mm})$, were added 0.2 eq of $\mathrm{ZnCl}_{2}\left(4 \mu \mathrm{L}\right.$ of a $2.5 \times 10^{-2} \mathrm{M}$ solution in $\left.\mathrm{D}_{3} \mathrm{CCN}\right)$. After each addition, the tube was heated at reflux during $5 \mathrm{~s}$, then cooled at room temperature, and the ${ }^{1} \mathrm{H} \mathrm{NMR}$ spectrum was recorded.

Guest binding: To $0.5 \mathrm{~mL}$ of closed tweezers $\mathbf{1}\left(2.0 \times 10^{-3} \mathrm{M}\right)$ dissolved in $\mathrm{CDCl}_{3}$ in an $\mathrm{NMR}$ tube $(5 \mathrm{~mm})$, were added coronene as a solid. After each addition, the tube was heated at reflux during $5 \mathrm{~s}$, then cooled at room temperature, and the ${ }^{1} \mathrm{H}$ NMR spectrum was recorded. 
UV-visible absorption spectra were recorded on a JASCO V-670 spectrophotometer at $25^{\circ} \mathrm{C}$. $\mathrm{CHCl}_{3}$ was dried over molecular sieves with a size of $4 \AA$ and neutralized on neutral $\mathrm{Al}_{2} \mathrm{O}_{3}$. Metal salts were used without any purification. The solutions of tweezers and metals salts used for titrations were prepared in volumetric flasks, before the additions were made with Hamilton syringes. The metal salt concentrations in the stock solutions were checked by titration with a terpyridine solution. Curve fitting were performed by a non-linear least-squares fit of the absorbance compared to the concentration of guest added using the Matlab program developed by Thordarson [50].

The titrations monitored by UV-Visible spectroscopy have been performed according to the following general procedure:

Tweezers 1 opening: To $3.0 \mathrm{~mL}$ of open tweezers $\left(5.0 \times 10^{-6} \mathrm{M}\right)$ dissolved in $\mathrm{CHCl}_{3}$ in a quartz cell $(10 \mathrm{~mm})$, were added $0.1 \mathrm{eq} \mathrm{ZnCl}_{2}\left(3 \mu \mathrm{L}\right.$ of $1.0 \times 10^{-3} \mathrm{M}$ solution in $\left.\mathrm{H}_{3} \mathrm{CCN}\right)$. After each addition, a UV-Visible absorption spectrum $\left(250-700 \mathrm{~nm}, 400 \mathrm{~nm} / \mathrm{min}, 25^{\circ} \mathrm{C}\right)$ was recorded.

$\left[\mathrm{Zn}(\mathbf{1})_{2}\right] \mathrm{Cl}_{2}$ closing: To $3.0 \mathrm{~mL}$ of closed tweezers $\left(5.0 \times 10^{-6} \mathrm{M}\right)$ dissolved in $\mathrm{CHCl}_{3}$ in a quartz

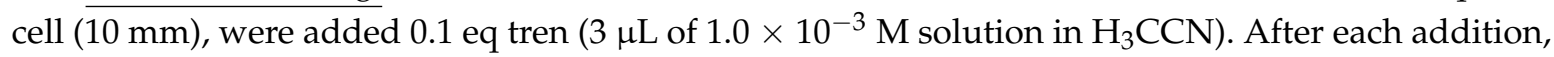
a UV-Visible absorption spectrum $\left(250-700 \mathrm{~nm}, 400 \mathrm{~nm} / \mathrm{min}, 25^{\circ} \mathrm{C}\right)$ was recorded.

\subsection{Computational Details}

Calculations were performed with the Gaussian 09 software [52]. Complete geometry optimizations were carried out using the density functional theory method with the conventional Becke-3-Lee-Yang-Parr (B3LYP) exchange-correlation functional and 6-31G**/LanL2DZ. The platinum atoms were modeled using the effective core potential and the corresponding valence orbitals LanL2DZ in order to decrease the number of basis functions. The other atoms were described by the double zeta $6-31 G^{* *}$ base, which takes into account the polarization orbitals of all atoms, including hydrogen atoms. Vibrational analysis was performed at the same level in order to check the obtaining of a minimum on the potential energy surface.

\section{Conclusions}

In conclusion, coordination-based switchable molecular tweezers with Pt-salphen moieties have been synthetized. By using an original 4,4" substituted terpyridine unit, the tweezers adopt a free 'U'-shaped closed conformation that can be reversibly converted by metal coordination to an open 'W'-shaped one. This new substitution pattern gives access to an opposite control of the mechanical motion compared to the previously reported 6,6" substituted switchable tweezers. The cavity formed by the Pt-salphen in the closed conformation enabled the binding of a coronene guest with the formation of a 1:1 complex. Such intercalation of an aromatic substrate was not possible in previous tweezers due to the presence of a cation near the cavity in the closed form. This demonstrates the interest of this new design, which will be exploited to achieve M-M interactions with guest complexes after further optimization of the binding sites.

Supplementary Materials: Supplementary materials are available online http:/ / www.mdpi.com/1420-3049/23/ 5/990/s1.

Author Contributions: G.V. and L.B. conceived and designed the experiments. L.B. and B.D. carried out the experimental work, analysis and interpretation of the results. B.H. supported and supervised the project. G.V. supervised the project and supported the analysis and interpretation of the results. All authors discussed the results and edited the manuscript.

Acknowledgments: Gordon Carley is acknowledged for assisting in the synthesis and titration experiments. Financial support from the ANR SMARTEES (15-CE07-0006-01) is acknowledged.

Conflicts of Interest: The authors declare no conflict of interest. 


\section{References}

1. Chen, C.W.; Whitlock, H.W. Molecular tweezers: A simple model of bifunctional intercalation. J. Am. Chem. Soc. 1978, 100, 4921-4922. [CrossRef]

2. Leblond, J.; Petitjean, A. Molecular Tweezers: Concepts and Applications. Chem. Phys. Chem. 2011, 12, 1043-1051. [CrossRef] [PubMed]

3. Hardouin-Lerouge, M.; Hudhomme, P.; Salle, M. Molecular clips and tweezers hosting neutral guests. Chem. Soc. Rev. 2011, 40, 30-43. [CrossRef] [PubMed]

4. Klärner, F.G.; Kahlert, B. Molecular Tweezers and Clips as Synthetic Receptors. Molecular Recognition and Dynamics in Receptor-Substrate Complexes. Acc. Chem. Res. 2003, 36, 919-932. [CrossRef] [PubMed]

5. Zimmerman, S. Rigid molecular tweezers as hosts for the complexation of neutral guests. Top. Curr. Chem. 1993, 165, 71-102.

6. Crowley, J.D.; Bosnich, B. Molecular Recognition: Use of Metal-Containing Molecular Clefts for Supramolecular Self-Assembly and Host-Guest Formation. Eur. J. Inorg. Chem. 2005, 2005, 2015-2025. [CrossRef]

7. Crowley, J.D.; Goshe, A.J.; Bosnich, B. Molecular recognition. Electrostatic effects in supramolecular self-assembly. Chem. Commun. 2003, 3, 392-393. [CrossRef]

8. Goshe, A.J.; Steele, I.M.; Bosnich, B. Supramolecular Recognition. Terpyridyl Palladium and Platinum Molecular Clefts and Their Association with Planar Platinum Complexes. J. Am. Chem. Soc. 2003, 125, 444-451. [CrossRef] [PubMed]

9. Goshe, A.J.; Steele, I.M.; Ceccarelli, C.; Rheingold, A.L.; Bosnich, B. Supramolecular recognition: On the kinetic lability of thermodynamically stable host-guest association complexes. Proc. Natl. Acad. Sci. USA 2002, 99, 4823-4829. [CrossRef] [PubMed]

10. Sommer, R.D.; Rheingold, A.L.; Goshe, A.J.; Bosnich, B. Supramolecular Chemistry: Molecular Recognition and Self-Assembly Using Rigid Spacer-Chelators Bearing Cofacial Terpyridyl Palladium(II) Complexes Separated by 7 Å. J. Am. Chem. Soc. 2001, 123, 3940-3952. [CrossRef] [PubMed]

11. Skibinski, M.; Gomez, R.; Lork, E.; Azov, V.A. Redox responsive molecular tweezers with tetrathiafulvalene units: Synthesis, electrochemistry, and binding properties. Tetrahedron 2009, 65, 10348-10354. [CrossRef]

12. Iordache, A.; Retegan, M.; Thomas, F.; Royal, G.; Saint-Aman, E.; Bucher, C. Redox-Responsive Porphyrin-Based Molecular Tweezers. Chem. Eur. J. 2012, 18, 7648-7653. [CrossRef] [PubMed]

13. Shinkai, S.; Nakaji, T.; Ogawa, T.; Shigematsu, K.; Manabe, O. Photoresponsive crown ethers. Photocontrol of ion extraction and ion transport by a bis(crown ether) with a butterfly-like motion. J. Am. Chem. Soc. 1981, 103, 111-115. [CrossRef]

14. Muraoka, T.; Kinbara, K.; Kobayashi, Y.; Aida, T. Light-Driven Open-Close Motion of Chiral Molecular Scissors. J. Am. Chem. Soc. 2003, 125, 5612-5613. [CrossRef] [PubMed]

15. Wang, J.; Hou, L.; Browne, W.R.; Feringa, B.L. Photoswitchable intramolecular through-space magnetic interaction. J. Am. Chem. Soc. 2011, 133, 8162-8164. [CrossRef] [PubMed]

16. Wezenberg, S.J.; Vlatković, M.; Kistemaker, J.C.M.; Feringa, B.L. Multi-State Regulation of the Dihydrogen Phosphate Binding Affinity to a Light- and Heat-Responsive Bis-Urea Receptor. J. Am. Chem. Soc. 2014, 136, 16784-16787. [CrossRef] [PubMed]

17. Leblond, J.; Gao, H.; Petitjean, A.; Leroux, J.C. pH-Responsive Molecular Tweezers. J. Am. Chem. Soc. 2010, 132, 8544-8545. [CrossRef] [PubMed]

18. Tsuchido, Y.; Suzaki, Y.; Ide, T.; Osakada, K. Dynamic Properties of Molecular Tweezers with a Bis(2-hydroxyphenyl)pyrimidine Backbone. Chem. Eur. J. 2014, 20, 4762-4771. [CrossRef] [PubMed]

19. Su, X.; Voskian, S.; Hughes, R.P.; Aprahamian, I. Manipulating Liquid-Crystal Properties Using a pH Activated Hydrazone Switch. Angew. Chem. Int. Ed. 2013, 52, 10734-10739. [CrossRef] [PubMed]

20. Zhang, X.; Ao, L.; Han, Y.; Gao, Z.; Wang, F. Modulating Pt[three dots, centered]Pt metal-metal interactions through conformationally switchable molecular tweezer/guest complexation. Chem. Commun. 2018, 54, 1754-1757. [CrossRef] [PubMed]

21. Barboiu, M.; Prodi, L.; Montalti, M.; Zaccheroni, N.; Kyritsakas, N.; Lehn, J.M. Dynamic Chemical Devices: Modulation of Photophysical Properties by Reversible, Ion-Triggered, and Proton-Fuelled Nanomechanical Shape-Flipping Molecular Motions. Chem. Eur. J. 2004, 10, 2953-2959. [CrossRef] [PubMed] 
22. Petitjean, A.; Khoury, R.; Kyritsakas, N.; Lehn, J.M. Dynamic devices. Shape switching and substrate binding in ion-controlled nanomechanical molecular tweezers. J. Am. Chem. Soc. 2004, 126, 6637-6647. [CrossRef] [PubMed]

23. Linke-Schaetzel, M.; Anson, C.E.; Powell, A.K.; Buth, G.; Palomares, E.; Durrant, J.D.; Balaban, T.S.; Lehn, J.M. Dynamic chemical devices: Photoinduced electron transfer and its ion-triggered switching in nanomechanical butterfly-type bis(porphyrin)terpyridines. Chem. Eur. J. 2006, 12, 1931-1940. [CrossRef] [PubMed]

24. Barboiu, M.; Legrand, Y.M.; Prodi, L.; Montalti, M.; Zaccheroni, N.; Vaughan, G.; van der Lee, A.; Petit, E.; Lehn, J.M. Modulation of Photochemical Properties in Ion-Controlled Multicomponent Dynamic Devices. Eur. J. Inorg. Chem. 2009, 2009, 2621-2628. [CrossRef]

25. Ulrich, S.; Lehn, J.M. Adaptation and Optical Signal Generation in a Constitutional Dynamic Network. Chem. Eur. J. 2009, 15, 5640-5645. [CrossRef] [PubMed]

26. Ulrich, S.; Petitjean, A.; Lehn, J.M. Metallo-Controlled Dynamic Molecular Tweezers: Design, Synthesis, and Self-Assembly by Metal-Ion Coordination. Eur. J. Inorg. Chem. 2010, 2010, 1913-1928. [CrossRef]

27. Li, Z.; Han, Y.; Gao, Z.; Fu, T.; Wang, F. Non-covalent molecular tweezer/guest complexation with Pt(II)-Pt(II) metal-metal interactions: Toward intelligent photocatalytic materials. Mater. Chem. Front. 2018, 2, 76-80. [CrossRef]

28. Doistau, B.; Cantin, J.L.; Chamoreau, L.M.; Marvaud, V.; Hasenknopf, B.; Vives, G. Mechanical switching of magnetic interaction by tweezers-type complex. Chem. Commun. 2015, 51, 12916-12919. [CrossRef] [PubMed]

29. Doistau, B.; Benda, L.; Hasenknopf, B.; Marvaud, V.; Vives, G. Switching Magnetic Properties by a Mechanical Motion. Magnetochemistry 2018, 4, 5. [CrossRef]

30. Doistau, B.; Benda, L.; Cantin, J.L.; Chamoreau, L.M.; Ruiz, E.; Marvaud, V.; Hasenknopf, B.; Vives, G. Six States Switching of Redox-Active Molecular Tweezers by Three Orthogonal Stimuli. J. Am. Chem. Soc. 2017, 139, 9213-9220. [CrossRef] [PubMed]

31. Wong, K.M.C.; Yam, V.W.W. Self-Assembly of Luminescent Alkynylplatinum(II) Terpyridyl Complexes: Modulation of Photophysical Properties through Aggregation Behavior. Acc. Chem. Res. 2011, 44, 424-434. [CrossRef] [PubMed]

32. Che, C.M.; Chan, S.C.; Xiang, H.F.; Chan, M.; Liu, Y.; Wang, Y. Tetradentate Schiff base platinum(II) complexes as new class of phosphorescent materials for high-efficiency and white-light electroluminescent devices. Chem. Commun. 2004, 13, 1484-1485. [CrossRef] [PubMed]

33. Jie, Z.; Fangchao, Z.; Xunjin, Z.; Wai-Kwok, W.; Dongge, M.; Wai-Yeung, W. New phosphorescent platinum(ii) Schiff base complexes for PHOLED applications. J. Mater. Chem. 2012, 22, 16448-16457.

34. Wu, W.; Sun, J.; Ji, S.; Wu, W.; Zhao, J.; Guo, H. Tuning the emissive triplet excited states of platinum(II) Schiff base complexes with pyrene, and application for luminescent oxygen sensing and triplet-triplet-annihilation based upconversions. Dalton Trans. 2011, 40, 11550-11561. [CrossRef] [PubMed]

35. Guo, Z.; Tong, W.L.; Chan, M.C.W. Axially rotating (Pt-salphen)2 phosphorescent coordination frameworks. Chem. Commun. 2009, 41, 6189-6191. [CrossRef] [PubMed]

36. Guo, Z.; Yiu, S.M.; Chan, M.C.W. Shape-Persistent (Pt-salphen)2 Phosphorescent Coordination Frameworks: Structural Insights and Selective Perturbations. Chem. Eur. J. 2013, 19, 8937-8947. [CrossRef] [PubMed]

37. Tong, W.L.; Yiu, S.M.; Chan, M.C.W. Crowded Bis-(M-salphen) $[\mathrm{M}=\mathrm{Pt}(\mathrm{II}), \mathrm{Zn}(\mathrm{II})]$ Coordination Architectures: Luminescent Properties and Ion-Selective Responses. Inorg. Chem. 2013, 52, 7114-7124. [CrossRef] [PubMed]

38. Doistau, B.; Tron, A.; Denisov, S.A.; Jonusauskas, G.; McClenaghan, N.D.; Gontard, G.; Marvaud, V.; Hasenknopf, B.; Vives, G. Terpy(Pt-salphen)2 Switchable Luminescent Molecular Tweezers. Chem. Eur. J. 2014, 20, 15799-15807. [CrossRef] [PubMed]

39. Doistau, B.; Rossi-Gendron, C.; Tron, A.; McClenaghan, N.D.; Chamoreau, L.M.; Hasenknopf, B.; Vives, G. Switchable platinum-based tweezers with $\mathrm{Pt}-\mathrm{Pt}$ bonding and selective luminescence quenching. Dalton Trans. 2015, 44, 8543-8551. [CrossRef] [PubMed]

40. Nabeshima, T.; Hasegawa, Y.; Trokowski, R.; Yamamura, M. Synthesis and guest recognition of molecular cleft consisting of terpyridine-Pt(II) acetylide complexes. Tetrahedron Lett. 2012, 53, 6182-6185. [CrossRef]

41. Tanaka, Y.; Man-Chung Wong, K.; Wing-Wah Yam, V. Phosphorescent molecular tweezers based on alkynylplatinum(II) terpyridine system: Turning on of NIR emission via heterologous Pt-M interactions (M = PtII, PdII, AuIII and AuI). Chem. Sci. 2012, 3, 1185-1191. [CrossRef] 
42. Tanaka, Y.; Wong, K.M.C.; Yam, V.W.W. Host-Guest Interactions of Phosphorescent Molecular Tweezers Based on an Alkynylplatinum(II) Terpyridine System with Polyaromatic Hydrocarbons. Chem. Eur. J. 2013, 19, 390-399. [CrossRef] [PubMed]

43. Ozawa, H.; Kuroda, T.; Harada, S.; Arakawa, H. Efficient Ruthenium Sensitizer with a Terpyridine Ligand Having a Hexylthiophene Unit for Dye-Sensitized Solar Cells: Effects of the Substituent Position on the Solar Cell Performance. Eur. J. Inorg. Chem. 2014, 2014, 4734-4739. [CrossRef]

44. Constable, E.C.; Hostettler, N.; Housecroft, C.E.; Kopecky, P.; Neuburger, M.; Zampese, J.A. $2,2^{\prime}: 6^{\prime}, 2^{\prime \prime}$-Terpyridine substituted in the $4^{\prime}$-position by the solubilizing and sterically demanding tert-butyl group: A surprisingly new ligand. Dalton Trans. 2012, 41, 2890-2897. [CrossRef] [PubMed]

45. Dobrawa, R.; Lysetska, M.; Ballester, P.; Grunea, M.; Wurthner, F. Fluorescent Supramolecular Polymers: Metal Directed Self-Assembly of Perylene Bisimide Building Blocks. Macromolecules 2005, 38, 1315-1325. [CrossRef]

46. Shunmugam, R.; Gabriel, G.J.; Aamer, K.A.; Tew, G.N. Metal-Ligand-Containing Polymers: Terpyridine as the Supramolecular Unit. Macromol. Rapid Commun. 2010, 31, 784-793. [CrossRef] [PubMed]

47. Gaizer, F.; Silber, H.B. Stability constants of zinc chloride complexes in DMSO-water mixtures. J. Inorg. Nucl. Chem. 1980, 42, 1317-1320. [CrossRef]

48. Gaizer, F.; Silber, H.B.; Lázár, J. Stability constants of zinc halide complexes in DMSO-water and DMF-water mixtures. Polyhedron 1985, 4, 1467-1470. [CrossRef]

49. Anderegg, G.; Gramlich, V. 1:1 Metal Complexes of Bivalent Cobalt, Nickel, Copper, Zink, and Cadmium with the Tripodal Ligand tris[2-(dimethylamino)ethyl]amine: Their stabilities and the X-ray crystal structure of its copper(II) complex sulfate. Helv. Chim. Acta 1994, 77, 685-690. [CrossRef]

50. Thordarson, P. Determining association constants from titration experiments in supramolecular chemistry. Chem. Soc. Rev. 2011, 40, 1305-1323. [CrossRef] [PubMed]

51. Tanaka, Y.; Wong, K.M.; Yam, V.W. Platinum-based phosphorescent double-decker tweezers: A strategy for extended heterologous metal-metal interactions. Angew. Chem. Int. Ed. 2013, 52, 14117-14120. [CrossRef] [PubMed]

52. Frisch, M.J.; Trucks, G.W.; Schlegel, H.B.; Scuseria, G.E.; Robb, M.A.; Cheeseman, J.R.; Scalmani, G.; Barone, V.; Mennucci, B.; Petersson, G.A.; et al. Gaussian 09; Gaussian, Inc.: Wallingford, CT, USA, 2009.

Sample Availability: Samples of the compounds 4 and $\mathbf{1}$ can be synthesized by the authors upon request.

(C) 2018 by the authors. Licensee MDPI, Basel, Switzerland. This article is an open access article distributed under the terms and conditions of the Creative Commons Attribution (CC BY) license (http://creativecommons.org/licenses/by/4.0/). 